has developed which seeks to give a psychological explanation of many forms of mental abnormality, and again the abnormal has thrown light on the normal. The pioneer work of Freud in this field, continued Sir Russell, has been as revolutionary in the interpretation of the mind as was the work of Darwin in the interpretation of the body. Freud did not discover the unconscious mind, for many thinkers deduced it from a study of human thought and behaviour; but he developed the idea practically and produced evidence to show that experiences involving strong emotions might continue to influence behaviour though they had been forgotten, and that feelings such as anxiety might persist divorced from the original ideas. Certain philosophical questions are involved; for example, why is consciousness necessary at all, and why is it associated with some functions of the brain and not with others? The recent contribution of medicine to our ideas of the mind have been, like most of modern science, analytical. But, as Sir Russell emphasized, medicine is also an art, and as an art must realize that the whole man is more than the sum total of parts. It is necessary, more than ever, to find a way of harmonizing logic, philosophy and humanity.

\section{FAO MEMO : New Leaflet of the United Nations Food and Agriculture Organization}

THE accounts of the activities of the Food and Agriculture Organization of the United Nations, available as yearbooks and other official publications, are often beyond the scope of the non-technical reader, who nevertheless is interested in the practical steps being taken to overcome hunger and raise the standard of living in various parts of the world. To meet the need of this section of the public, the Organization has started a new illustrated leaflet, $F A O M E M O$, which gives, in semi-popular form, short authentic accounts of its very varied work. In the first issue, which appeared in March, one learns of the success of the publicity campaign in Santiago for encouraging the production and consumption of fish, and in the following number of the project for turning the Jizan region of Saudi Arabia, liable to disastrous extremes of drought and flood, into a flourishing agricultural district by controlling the water supply. Accounts are also given of the useful work being done in the development of rural community life in the Pátzcuaro Lake region of Mexico, and of some occasions, notably that of the recent hurricane in Jamaica, when valuable technical assistance was provided. The $M E M O$ is published monthly by the Informational and Educational Services in Rome of the Food and Agriculture Organization, and by the Regional Information Offices in Bangkok, Cairo, New Delhi, Mexico City, and Washington, D.C. Copies of the European edition can be obtained from the Documents Service, Food and Agriculture Organization, Viale delle Terme di Caracalla, Rome, and of the other editions from the appropriate regional offices.

\section{Food and Agriculture Organization: David Lubin Memorial Library}

AT a formal ceremony on June 10 the library of the Food and Agriculture Organization of the United Nations was inaugurated in Rome by the directorgeneral, Norris E. Dodd, in the presence of the Council of the Organization, the American Ambassador to Italy, the Italian Minister of Agriculture and representatives of members of the Food and Agriculture Organization. The children and the secretary of David Lubin, founder of the Institut International de l'Agriculture and of its library of some 350,000 publications, which now forms the most substantial and important part of the Food and Agriculture Organization's library of some 400,000 works were among the guests at the opening ceremony. Housed in the modern building generously made available by the Italian Government, the library contains reading rooms, reference, photostat, microfilm services and eighteen kilometres of shelves. In opening it to the public, Mr. Dodd said, "It is a living resource for the service of the world's agriculture. We wish to make it as open as possible to all scholars and technicians and research workers".

\section{Scientific and Technical Periodicals Published in} East Asia

The East Asia Science Co-operation Office, Manila, has issued a list, compiled in 1950, of scientific and technical periodicals published in South-East Asia. The periodicals are listed separately under the Philippines, Indonesia, Malaya, Thailand, Indo-China and Hong Kong, but for each country they are arranged in fourteen broad categories and are also entered in an index by categories covering all six countries. The list covers 142 periodicals and includes particulars of publishers and rates of subscriptions. There is, in addition, an alphabetical index to periodicals arranged under countries. The Office has also issued a supplement to the list, which gives details of some 119 Chinese periodicals. This was compiled in the Shanghai bureau of the Office at the end of 1950 and was revised in the summer of 1951. The supplement is considered incomplete, especially for periodicals published outside Shanghai. Titles are listed alphabetically and also classified by subjects, and particulars of publishers, language, frequency, subscription and commencement of publication are included. The co-operation of scientific workers and librarians in repairing omissions and correcting errors in the list as a whole is invited.

\section{British Thomson-Houston Engineering Research Fellowships}

THE British Thomson-Houston Co., Ltd., has instituted the award (annually) of engineering research fellowships. The award is open to honours graduates who are in their last year of apprenticeship with the Company. The holder of a fellowship will engage in engineering research for a limited period (one to three years) either wholly within the Company or partly within the Company and partly at a university. He will work under the supervision of a senior engineer of the Company and under the guidance of a Research Fellowship Panel set up for the purpose. The Director of Research and Education is chairman of the Panel, which includes other senior executives of the Company and, in addition, Prof. E. B. Moullin and Prof. Willisw Jackson. This year (1952) fellowships have been awarded to P. H. G. Allen and P. C. MeNeill. Mr. Allen was educated at King Edward VI Grammar School, and the City College, Norwich. During the War he served with the Royal Engineers and was a prisoner-of-war in Japan for three and a half years. On demobilization, he studied at King's College, London, and obtained his degree in electrical engineering with first-class honours in 1950 . His research will be concerned with heat flow in large transformers. Mr. McNeill was educated at Loretto School, Midlothian. During the 